\title{
HUBUNGAN PENGETAHUAN DAN KARAKTERISTIK AKSEPTOR DENGAN PENGGUNAAN PELAYANAN KB JALUR SWASTA DI JAWA BARAT
}

\author{
The Relationship of Knowledge and Characteristics of Acceptors with the Use \\ of Private Pathway Services in West Java
}

Enadarlita

\author{
Widyaiswara BPSDM Provinsi Jambi \\ e-mail: enadarlita@yahoo.com
}

\begin{abstract}
:
This study aims to: 1) find out information about acceptor knowledge with the use of private line $K B$ services. 2) Information about the relationship between the demographic characteristics of acceptors and the use of family planning KB services is known. 3) Information about the relationship between acceptors' socio-economic characteristics and the use of family planning services through private channels is known. 4) Information about the relationship between the characteristics of the acceptor's social environment and the use of family planning family planning services are known. 5) Information about the relationship between acceptor knowledge, demographic characteristics, socio-economic characteristics, and characteristics of the acceptor social environment with the use of family planning KB services. The research method used is the analysis of Indonesian health demographic survey data to study the relationship between acceptor characteristics and the use of private line $K B$ services. The statistical analysis performed is a different proportion test $\left(X^{2}\right)$, and a simple and multiple logistic regression test. The study design was 'cross sectional'. The results showed that the age of the smallest child, the education of the respondent, the education of the husband, the type of work of the husband, the knowledge of the private path, the ownership of household goods, the cost and place of residence had a relationship with the use of family planning KB services. Some independent variables show a very close relationship (education, the type of work of the husband, ownership, cost and place of residence). In addition there are differences in risk (interaction) between acceptors who know the private line $K B$ services with the education of respondents with the use of private line $K B$ services..
\end{abstract}

Keyword : Knowledge, Characteristics of Respondents, use of Private Road KB

\begin{abstract}
Abstrak
Penelitian ini bertujuan untuk .1) mengetahui informasi tentang pengetahuan akseptor dengan penggunaan pelayanan KB jalur swasta. 2) Diketahuinya informasi tentang hubungan antara karakteristik demografi akseptor dengan pengguaan pelayanan KB jalur swasta. 3) Diketahuinya informasi tentang hubungan antara karakteristik sosial ekonomi akseptor dengan penggunaan pelayanan KB melalui jalur swasta. 4) Diketahuinya informasi tentang hubungan antara karakteristik lingkungan sosial akseptor dengan penggunaan pelayanan KB jalur swasta. 5) Diketahuinya informasi tentang antar hubungan pengetahuan akseptor, karakteristik demografi, karakteristik sosial ekonomi, dan karakteristik lingkungan sosial akseptor dengan penggunaan pelayanan KB jalur swasta. Metode penelitian yang digunakan adalah analisis data survey demografi kesehatan Indonesia untuk mempelajari hubungan antara karakteristik akseptor dengan penggunaan pelayanan KB jalur swasta. Analisis statistik yang dilakukan adalah uji beda proporsi ( $\left.X^{2}\right)$, dan uji regresi logistic secara sederhana dan ganda. Desain penelitian adalah 'cross sectional'. Hasil penelitian menunjukkan bahwa umur anak terkecil, pendidikan responden, pendidikan suami, jenis pekerjaan suami, pengetahuan jalur swasta, pemilikan barang rumah tangga, biaya dan tempat tinggal mempunyai hubungan dengan penggunaan pelayanan KB jalur swasta. Beberapa variable bebas menunjukkan hubungan yang sangat erat (pendidikan, jenis pekerjaan suami, pemilikan, biaya dan tempat tinggal). Selain itu ada perbedaan resiko (interaksi) antara akseptor yang mengetahui pelayanan KB jalur swasta dengan pendidikan responden dengan penggunaan pelayanan KB jalur swasta.
\end{abstract}

Kata Kunci : Pengetahuan, Karakteristik Responden, Penggunaan KB Jalur Swasta.

402 |Khazanah Intelektual Volume 3 Nomor 1 Tahun 2019 


\section{PENDAHULUAN}

Keluarga

(KB) merupakan

suatu

Berencana

pemerintah yang dirancang untuk menyeimbangkan antara kebutuhan dan jumlah penduduk. Adapun tujuan Program keluarga berencana tersebut agar keluarga sebagai unit terkecil kehidupan bangsa diharapkan menerima Norma Keluarga Kecil Bahagia dan Sejahtera (NKKBS) yang berorientasi pada pertumbuhan yang seimbang.

Gerakan Keluarga Berencana Nasional Indonesia telah berumur sangat lama yaitu pada tahun 70-an dan program tersebut dilndonesia cukup berhasil menurunkan angka kelahiran yang bermakna.Namun demikian jumlah penduduk Indonesia merupakan salah satu Negara dengan jumlah penduduk terbanyak di Dunia.

Jika dilihat dari urutannya di dunia, Indonesia merupakan Negara dengan Jumlah Penduduk Terbanyak keempat di Dunia. Berdasarkan data yang dipublikasikan oleh Badan Pusat Statistik (BPS) pada tahun 2017 yang berjudul Statistik Indonesia
2017 (Statistical Yearbook of Indonesia 2017), Jumlah Penduduk Indonesia adalah sebanyak 258.704.900 jiwa pada tahun 2016 . Angka tersebut lebih tinggi sekitar $8,5 \%$ atau bertambah sebanyak 20.186.200 jiwa dibandingkan dengan tahun 2015 yang berjumlah 238.518.800 jiwa. Jumlah Penduduk Indonesia yang tersebar di 34 Provinsi di Indonesia. Berdasarkan data Badan Pusat Statistik ini, Provinsi yang memiliki jumlah penduduk terbanyak adalah provinsi Jawa Barat memiliki jumlah penduduk sebanyak 47.379.400 jiwa atau sekitar 18,3\% dari keseluruhan jumlah penduduk di Indonesia. Provinsi yang berada di urutan kedua sebagai provinsi dengan jumlah penduduk terbanyak adalah Jawa Timur dengan jumlah penduduk sebanyak 39.075.300 jiwa $(15,1 \%)$.

Provinsi Jawa Tengah yang memiliki jumlah penduduk sebanyak 34.019.100 jiwa (13,1\%) ini berada di urutan ketiga sebagai provinsi dengan jumlah penduduk terbanyak ketiga di Indonesia Statistik Indonesia 2017, Badan Pusat Statistik (BPS) Indonesia. 
Laju pertumbuhan penduduk (LPP) Indonesia berdasarkan hasil sensus penduduk tahun 2010 sebesar 1,49\%, menurut bank dunia tahun 2018 telah terjadi penurunan menjadi $1,2 \%$. LPP yang semakin menurun tersebut salah satunya disebabkan keberhasilan gerakan keluarga berencana (KB). Keberhasilan lain pelaksanaan Gerakan Keluarga Berencana Nasional secara kuantitatif berupa peningkatan jumlah peserta KB baru, jumlah peserta KB aktif dan penurunan tingkat kelahiran. Secara kualitatif berupa perubahan persepsi dan perilaku masyarakat yang semakin menghayati arti pentingnya norma keluarga kecil bahagia dan sejahtera (NKKBS). Selama ini keberhasilan program KB tersebut berada ditangan pemerintah, Dalam upaya mengurangi peran sarana pemerintah, BKKBN merasa perlu untuk mengembangkan strategi yang tepat, guna mencapai kondisi agar tujuan KB mandiri dapat dicapai, salah satunya adalah melibatkan sektor swasta dalam pelayanan kontrasepsi (RS. Swasta, klinik swasta, dokter praktek swasta, bidan praktek swasta, apotik/toko obat, dII).
Karena keterlibatan sektor swasta dapat meringankan beban pemerintah supaya tidak seluruh pelayanan harus ditanggung sendiri oleh pemerintah.

Salah satu ciri kemandirian adalah berkembangnya sector swasta. Dimana pada era kemandirian orientasi "supply" akan bergeser keorientasi "demand", yang ditentukan oleh demand, keinginan dan selera masyarakat. Sedangkan provinder lebih banyak melayani aspirasi masyarakat tersebut (Suyono Haryono , 1987;2). Inti dari strategi kemandirian ini adalah menciptakan rasa percaya diri warga masyarakat akan kualitas sarana pelayanan KB swasta dan kualitas alat kontrasepsi yang disediakan (Prihartono Judo, 1994;669, dan Perwira, 1992).

Secara resmi program keluarga berencana telah dilaksanakan sejak tahun 1970 di semua provinsi yang ada di pulau Jawa dan Bali termasuk Jawa Barat. Dengan adanya gerakan ini akan memperluas sarana pelayanan KB, karena bidang pelayanan yang melimpah dan beragam sudah barang tentu memperbaiki kualitas dan jangkauan 
program-program KB dibanyak Negara (Jason L Finkle dan C. Alison Mchitosh, 1994; 4).

\section{Kajian Teori}

Untuk mengetahui keberhasilan gerakan keluarga berencana mandiri (GKBM) diperlukan tolok ukur keberhasilannya (BKKBN, 1990;16).

Tolok ukur tersebut adalah: Jumlah sektor swasta yang berpartisipasi dalam GKBM, Persentase peserta $\mathrm{KB}$ mandiri disuatu wilayah. Keterlibatan sektor swasta dalam pelayanan KB merupakan salah satu bentuk kerjasama yang dilakukan dalam upaya memenuhi permintaan masyarakat akan pelayanan KB dan kesehatan reproduksi yang berkualitas. Berdasarkan Survei Demografi dan Kesehatan Indonesia (SDKI) tahun 2007 tercatat 69,1 persen peserta KB dilayani oleh swasta, 22 persen dilayani oleh pemerintah, dan 7,6 persen lewat pelayanan lain, seperti polindes dan posyandu. Pada fasilitas pelayanan pemerintah, tingkat kemandirian berKB makin menurun dari $21,2 \%$ pada SDKI 2003 menjadi 16,7\% pada 2007.

Sedangkan tingkat kemandirian ber-KB (membayar) di tempat pelayanan swasta makin meningkat, dari $59,2 \%$ pada Survei Demografi Kesehatan Indonesia (SDKI) 2003 menjadi 66,9\% pada SDKI 2007.

Mandiri adalah suatu sikap mental yang sanggup berdiri sendiri dan tidak tergantung pada orang lain. Keluarga berencana mandiri berarti pelaksanaan KB dari seseorang atau kelompok yang tidak tergantung pada orang lain atau pihak lain (sumarsono, 1987; 8).

Kemandirian ini dapat dilihat dari dua aspek sebagai berikut: 1) Aspek individu, yang mempunyai arti bahwa seseorang yang dalam memenuhi kebutuhan KB-nya mampu berdiri sendiri atau membiayai sendiri. Menurut Sumarsono, mandiri disini tidak dapat diartikan dengan hal-hal yang sempit dan phisik, misalnya mandiri berarti telah sanggup membayar. 2) Aspek kelompok / organisasi, merupakan organisasi pengelola KB mandiri, dimana mereka dalam melaksanakan kegiatan pelayanan KB telah mampu menggunakan data, daya dan sarana dari organisasinya sendiri.

Perilaku manusia merupakan hasil dari pada segala macam 
pengalaman serta interkasi manusia dengan lingkungannya yang terwujud dalam bentuk sikap dan tindakan (Sarwono, 1993). Perilaku dipandang dari segi biologis adalah suatu kegiatan/aktifitas organism yang bersangkutan (Notoatmojo, 1993;). Katz menyatakan, perilaku merupakan respon/reaksi seorang individu terhadap stimulus yang berasal dari luar maupun dari dalam dirinya. Perilaku dilatar belakangi oleh kebutuhan individu yang bersangkutan (Notoatmojo, 1993).

Perubahan perilaku individu baru dapat menjadi optimal jika perubahan tersebut terjadi melalui proses internalisasi dimana perilaku yang baru itu dianggap bernilai positif bagi diri individu itu sendiri dan diintegrasikan dengan nilai lain dari hidupnya (Sarwono, 1993).

Perjuangan melembagakan dan membudayakan KB mandiri ini sangat tergantung keadaan yang melingkupi sosial budaya masyarakat maupun persepsi masyarakat. Selain itu juga keadaan phisik, yakni berupa tersedianya sarana-sarana pelayanan yang diperlukan. Lawrence W. Green (1980) mengatakan bahwa perilaku seseorang terhadap sesuatu obyek dipengaruhi oleh 3 faktor yaitu:

1).Faktor yang memudahkan (Predisposing factors) 2). Faktor pemungkin (Enabling faktors) 3).Faktor penguat (Reinforcing faktors). Faktor predisposisi, merupakan faktor anteseden terhadap perilaku yang menjadi dasar atau motivasi bagi perilaku. Yang termasuk dalam faktor ini adalah pengetahuan, sikap, keyakinan, nilai dan variabel demografi tertentu. Faktor pemungkin, adalah faktor anteseden terhadap perilaku yang memungkinkan suatu motivasi atau aspirasi terlaksana.Termasuk didalamnya keterampilan dan sumber daya pribadi disamping sumber daya kominiti. Faktor penguat, merupakan faktor penyerta. Yang termasuk dalam faktor ini adalah manfaat sosial dan jasmani dan ganjaran nyata maupun tidak nyata yang pernah diterima pihak lain.

Hasil perumusan Seminar Quality Assurance di Cisarua (1994), dirumuskan bahwa pelayanan KB swasta secara umum dibedakan dalam : 1). Pelayanan klinik (clinical 
based) yang dimanfaatkan untuk pelayanan kontrasepsi dan konseling khusus. 2). Pelayanan oleh masyarakat (community based) dimanfaatkan untuk pelayanan kontrasepsi sederhana ulang (pil, kondom, intrafag), pelayanan konseling kontrasepsi dan reproduksi sehat serta melaksanakan rujukan. 3). Pelayanan oleh sektor swasta (dokter, bidan, spesialis) yang dimanfaatkan untuk pelayanan kontrasepsi (MOP,MOW,IUD, Implan. Suntikan, pil, kondom) pelayanan konseling khusus dan melaksanakan rujukan.

Program pelayanan swasta dimana sebagian atau seluruh biaya dibebankan kepada akseptor, hukum pasar menunjukan bahwa pelayanan yang lebih baik dengan harga yang tepat akan menarik lebih banyak klien. Sedangkan pada programprogram pemerintah baik diklinik maupun di masyarakat terlihat bahwa kualitas pelayanan akan meningkatkan peserta KB baru dan memantapkan pemakaian kontrasepsi (Brunce, 1989).

Model penggunaan pelayanan kesehatan Anderson dan Anderson (1979) menggunaka tujuh kategori yang didasarkan pada tipe-tipe variable yang digunakan sebagai determinasi-determinasi penggunaan pelayanan kesehatan. Kategori dari model-model penggunaan pelayanan kesehatan tersebut : 1) Model Demografi. Dalam model ini tipe variable-variabel yang dipakai adalah umur, seks, status perkawinan, besarnya keluarga. Karakteristik demografi ini berhubungan dengan karakteristik sosia (perbedaan sosial dari jenis kelamin mempengaruhi berbagai tipe dan cirri-ciri sosial. 2) Model sturuktur sosial (social structur model). Dalam model ini variable yang dipakai adalah pendidikan, pekerjaan, kebangsaan. Model ini mencerminkan sosial dari individu atau keluarga dalam masyarakat. Yang memperlihatkan berbagai gaya kehidupan dari individu-individu dan keluarga dari kedudukan sosial tertentu. Penggunaan pelayanan kesehatan adalah salah satu aspek dari gaya hidup yang ditentukan oleh tingkat sosial. Variabel yang dipakai dalam model ini adalah ukuran sikap dan keyakinan individu. 3) Model sumber keluarga (family resource models). Variabel yang dipakai dalam model ni adalah pendapatan 
keluarga, cakupan asuransi keluarga atau sebati anggota suatu asuransi kesehatan dan pihak yang mempunyai pelayanan kesehatan keluarga dan sebagainya. 4) Model sumber keluarga berdasarkan model ekonomis. Model sumber daya masyarakat (community resource models). Variabel yang digunakan dalam model ini adalah penyediaan pelayanan kesehatan dan sumbersumber didalam masyarakat dan ketercapaian dari pelayanan kesehatan yang tersedia. 5) ModelModel organisasi (organization models) Dalam model variabel yang dipakai adalah pencerminan perbedaan bentuk-bentuk sistem pelayanan kesehatan. Variabel yang digunakan adalah: Gaya (style) praktek pengobatan (sendiri, rekanan atau kelompok). Sifat (nature) dari pelayanan tersebut (membayar langsung atau tidak). Letak dari pelayanan kesehatan (tempat pribadi, RS/klinik). Petugas kesehatan yang pertama kali kontak dengan pasien (dokter, perawat, asisten dokter). 6).Model sistemsistem kesehatan.

Anderson

menggambarkan model sistem kesehatan (health system model) berupa model kepercayaan kesehatan. Yang terdiri dari 3 kategori utama dalam pelayanan kesehatan, yaitu : karakteristik kebutuhan. Penjabaran dari masingmasing karakteristik tersebut sebagai berikut:1) Karakteristik (predisposisi (predisposing characteristics). Karakteristik ini digunakan untuk menggambarkan fakta bahwa tiap individu mempunyai kecendrungan untuk menggunakan pelayanan kesehatan yang berbeda-beda. Hal ini karena adanya cirri-ciri individu, yang digolongkan dalam 3 kelompok: a.Ciri-ciri demografi, seperti jenis kelamin, umur. b.Struktur sosial, seperti tingkat pendidikan, pekerjaan, kesukuan /ras dsb. c. Manfaat kesehatan, seperti keyakinan bahwa pelayanan kesehatan dapat menolong proses penyembuhan penyakit. Selanjutnya Anderson percaya bahwa setiap individu mempunyai perbedaan karakteristik, tipe, frekuensi penyakit, pola penggunaan pelayanan kesehatan, perbedaan struktur sosial, perbedaan gaya hidup, dan individu percaya adanya kemanjuran dalam penggunaan pelayanan 
kesehatan.2).

pendukung

characteristics). Karakteristik ini

mencerminkan bahwa meskipun mempunyai predisposisi untuk menggunakan pelayanan kesehatan, ia tak akan bertindak untuk menggunakannya, kecuali bila ia mampu menggunakannya.

Penggunaan pelayanan kesehatan tergantung kepada kemampuan konsumen untuk membayar. 3). Karaktersitik kebutuhan (need characteristics).

Hasil-hasil penelitian terdahulu tentang keluarga berencana jalur swasta (mandiri).

Banyak faktor yang menyebabkan pasangan usia subur (PUS) menggunakan pelayanan KB jalur swasta, antara lain penghasilan yang cukup atau berlebih menyebabkan PUS memilih pelayanan $\mathrm{KB}$ jalur swasta (Fhatonah, 1992). Hasil penelitian Aryekti Kanthi (2000) Persepsi pemakai pelayanan tentang kualitas pelayanan KB memiliki hubungan signifikan dengan pemilihan jalur pelayanan KB. Nilai OR=51,1539 $(95 \% \quad \mathrm{Cl}=17,06-153,34) \quad$ dengan $\mathrm{p}=\mathrm{O}, 0000$. Variabel umur dan pendidikan memiliki hubungan signifikan juga dengan pemilihan jalur pelayanan $\mathrm{KI} 3$. Nilai OR untuk variabel umw3,1780 $(95 \% \mathrm{Cl}=1,13-$ 8,93) dengan $\mathrm{p}=\mathrm{O}, \mathrm{O} 283$. Nilai $\mathrm{OR}$ untuk variabel pendidikan $=6,6756$ (95\% $\quad \mathrm{Cl}=\mathrm{I}, \quad 17-38, \mathrm{O}) \quad$ dengan $\mathrm{p}=0,0327$. memiliki hubungan Pendapatan dan keterjangkauan tempat pelayanan $\mathrm{K} \mathrm{B}$ ti\& signifikan dengan pemilihan jalur pelayanan KI3. Nilai OR untuk variabel pendapatan $=0,4128 \quad(95 \% \quad \mathrm{Cl}=\mathrm{O}, 13-$ 1,33 ) dengan $p=0,1383$. Nilai $O R$ untuk variabei keterjangkauan tempt pelayanan $\quad \mathrm{KB}=1,8880 \quad(95 \%$ $\mathrm{Cl}=0,63-5,68) \quad$ Menurut hasil penelitian yang dilakukan oleh Ida bagus permana diketahui bahwa variabel Pendidikan, baik pendidikan isteri maupun pendidikan suami memegang peranan penting dalam pemilihan tempat pelayanan kontrasepsi. Makin tinggi pendidikan PUS semakin besar kemungkinan memilih pelayanan KB jalur swasta., disamping itu alasan pokok yang dikemukakan responden tentang pemilihan tempat pelayanan $\mathrm{KB}$ adalah factor jarak atau kemudahan mencapai tempat pelayanan tersebut (75\%) responden mengatakan 
bahwa alasan memlih tempat pelayanan karena dekat dengan rumah.

Dari hasil penelitian yang dilakukan oleh Muthalib, DKK di Jambi diketahui bahwa responden yang berpendidikan lebih tinggi serta ekonomi yang lebih baik memperoleh pelayanan KB melalui jalur mandiri, dan yang menghambat peningkatan penggunaan pelayanan $\mathrm{KB}$ mandiri adalah karena kurangnya informasi tentang $\mathrm{KB}$ mandiri. Kepandaian baca tulis memudahkan penyebaran keteranggan tentang $\mathrm{KB}$ (Eckhom Erik dan Newland Kathleen. 1977). Penelitian di Yordania (1972) mengenai pendapat wanita tentang $\mathrm{KB}$ ternyata ada kaitan yang erat antara tingkat pendidikan dengan sikap terhadap KB. Wanita yang buta huruf $80 \%$ menyatakan tidak setuju dengan $\mathrm{KB}$ wanita yang berpendidikan tinggi rata-rata setuju dengan $\mathrm{KB}$. Pendidikan seseorang berpengaruh dalam memberikan respon terhadap sesuatu yang datang dari luar. Orang yang berpendidikan tinggi akan memberikan respon yang lebih rasional dibandingkan mereka yang berpendidikan rendah.
Achmad Salim Djawas dalam penelitiannya menemukan bahwa semakin sering PUS mengikuti pertemuan tentang $\mathrm{KB}$ akan meningkatkan kemandirian akseptor. Dalam penelitian yang sama juga diketahui bahwa semakin mudah mencapai lokasi pelayanan dan waktu yang singkat makin tinggi kemandirian. Dari segi pemberi pelayanan diketahui bahwa $85 \%$ dokter praktek swasta telah menyelenggrakan pelayanan KB, namun antara dokter umum dengan dokter ahli kebidanan terdapat persentase yang berbeda, dokter umum menyelenggarakan pelayanan KB 91,4\% sedangkan dokter ahli 57\% (Setyawati, 1988).

Jumlah anak juga berpengaruh terhadap kemandirian seseorang dalam ber KB dari hasil penelitian Supriyoko, DKK mengemukakan bahwa akseptor yang mempunyai anak 2 orang telah menjadi perserta KB dengan pola mandiri penuh $(35 \%)$, sedangkan akseptor yang memiliki anak 5 atau lebih tingkat kemandiriannya paling rendah $(11,67 \%)$ dan sebagian besar memperoleh pelayanan $\mathrm{KB}$ melalui bidan (70\%). Namun dalam 
penelitian ini ternyata ada perbedaan dari hasil penelitian lainnya dimana ternyata pendidikan dalam hasil penelitian ini tidak berpengaruh terhadap tingkat kemandirian dalam ber KB. Gelora Manurung dalam penelitiannya mengatakan bahwa alasan akseptor memilih pelayanan KB melalui dokter praktek swasta adalah karena pelayanannya baik/cepat dan tidak antri. Hasil penelitian KB mandiri yang dilakukan oleh Sylvana pengemana, dkk pada 6 provinsi diperoleh hasil bahwa sebagian besar akseptor KB berusia 20-35 tahun memperoleh pelayanan KB melalui bidan praktek. Yang berkunjung ke prakterk dokter spesialis berusia lebih tua

\section{Kerangka Berfikir :}

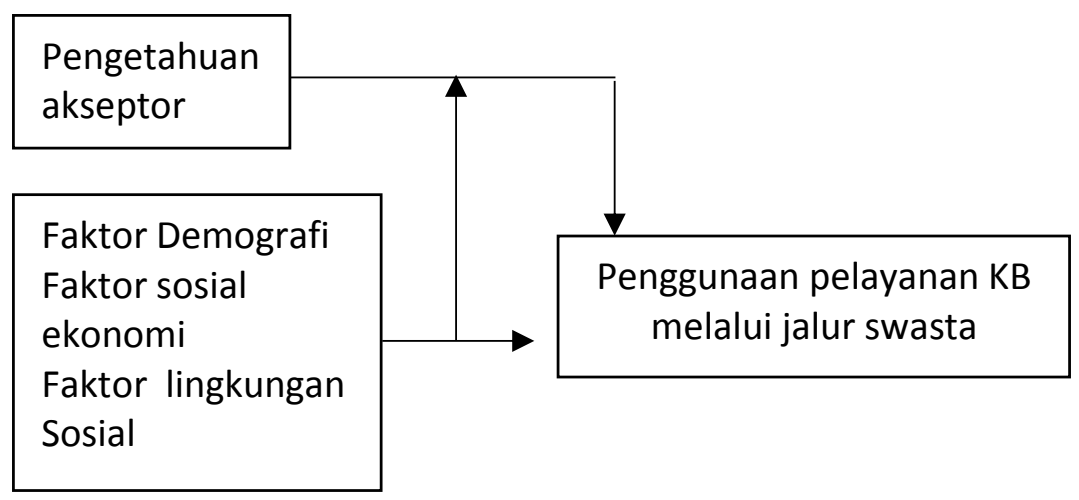

Gambar.1 Faktor-faktor yang mempengaruhi penggunaan pelayanan KB melalui jalur swasta

\section{METODOLOGI PENELITIAN}

Penelitian ini merupakan studi analitik terhadap data sekunder dari survei Demografi dan kesehatan Indonesia (SDKI). Rancangan yang digunakan dalam penelitian ini adalah : Studi cross penelitian. Populasi dan sampel penelitian adalah wanita yang berstatus kawin yang berumur 15-49 tahun yang ada di provinsi Jawa Barat. Sedangkan pemilihan sampel dalam survei
Demografi dan kesehatan Indonesia (SDKI) dirancang berdasarkan ratio dengan menggunakan Multistage random sampling yaitu dengan membagi Indonesia atas 3 strata yang terdiri dari Jawa Bali, luar jawa Bali I (LJB I) dan luar Jawa Bali II (LJB II). Dengan menggunakan angka rata-rata wanita pernah kawin umur 15-49 tahun sebesar 0.8 wanita yang memenuhi syarat. 
HASIL PENELITIAN DAN PEMBAHASAN

Tabel.1 Distribusi akseptor berdasarkan karaktersitik demografi, sosial ekonomi dan lingkungan sosial

\begin{tabular}{|c|c|c|c|c|c|c|c|}
\hline No & Variabel & Jumlah & $\%$ & No & Variabel & Jumlah & $\%$ \\
\hline 1 & $\begin{array}{l}\text { Umur Responden } \\
<20 \text { tahun } \\
20-30 \text { tahun } \\
>30 \text { tahun } \\
\end{array}$ & $\begin{array}{l}119 \\
1127 \\
882 \\
\end{array}$ & $\begin{array}{l}5,60 \\
52,95 \\
41,46 \\
\end{array}$ & 7 & $\begin{array}{l}\text { Jenis pekerjaan suami } \\
\text { Petani } \\
\text { Bukan petani }\end{array}$ & $\begin{array}{l}753 \\
1375\end{array}$ & $\begin{array}{l}35,40 \\
64,50\end{array}$ \\
\hline 2 & $\begin{array}{l}\text { Jumlah anak hidup } \\
\leq 2 \text { orang } \\
>2 \text { orang }\end{array}$ & $\begin{array}{r}646 \\
1482\end{array}$ & $\begin{array}{c}30,40 \\
69,60\end{array}$ & 8 & $\begin{array}{l}\text { Pemilikan } \\
\text { Tidak punya } \\
1 \text { barang } \\
2-3 \text { barang } \\
\text { Semua barang (4) }\end{array}$ & $\begin{array}{l}634 \\
766 \\
537 \\
191 \\
\end{array}$ & $\begin{array}{l}29,80 \\
36,00 \\
25,30 \\
8,90 \\
\end{array}$ \\
\hline 3 & $\begin{array}{l}\text { Umur anak tere } \\
>2 \text { tahun } \\
\leq 2 \text { tahun }\end{array}$ & $\begin{array}{l}920 \\
1208\end{array}$ & $\begin{array}{c}43,20 \\
56,80\end{array}$ & 9 & $\begin{array}{l}\text { Biaya } \\
\text { Gratis } \\
\text { Rendah } \\
\text { Sedang } \\
\text { Tinggi }\end{array}$ & $\begin{array}{l}69 \\
1133 \\
621 \\
133 \\
\end{array}$ & $\begin{array}{l}3,50 \\
57,90 \\
31,70 \\
6,80 \\
\end{array}$ \\
\hline 4 & $\begin{array}{l}\text { Pendidikan } \\
\text { responden } \\
\text { Tidak sekolah } \\
\text { Tidak tamat SD } \\
\text { Tamat SD } \\
\text { SLTP keatas } \\
\end{array}$ & $\begin{array}{l}328 \\
738 \\
740 \\
322\end{array}$ & $\begin{array}{l}15,20 \\
34,80 \\
34,70 \\
15,40\end{array}$ & 10 & $\begin{array}{l}\text { Tempat tinggal } \\
\text { Di desa } \\
\text { Di kota }\end{array}$ & $\begin{array}{l}1409 \\
719\end{array}$ & $\begin{array}{l}66,20 \\
33,80\end{array}$ \\
\hline 5 & $\begin{array}{l}\text { Pendidikan suami } \\
\text { Tidak sekolah } \\
\text { Tidak tamat SD } \\
\text { Tamat SD } \\
\text { SLTP keatas }\end{array}$ & $\begin{array}{l}185 \\
664 \\
726 \\
553 \\
\end{array}$ & $\begin{array}{l}8,70 \\
31,20 \\
34,10 \\
25,99 \\
\end{array}$ & 11 & $\begin{array}{l}\text { Petugas KB } \\
\text { Tidak ada } \\
\text { Tidak ada }\end{array}$ & $\begin{array}{l}1289 \\
839\end{array}$ & $\begin{array}{l}60,60 \\
39,40\end{array}$ \\
\hline 6 & $\begin{array}{l}\text { Tempat tinggal } \\
\text { Di desa } \\
\text { Di kota }\end{array}$ & $\begin{array}{l}1409 \\
719\end{array}$ & $\begin{array}{l}66,20 \\
33,80\end{array}$ & 12 & $\begin{array}{l}\text { Waktu } \\
\text { Singkat } \\
\text { Sedang } \\
\text { Lama }\end{array}$ & $\begin{array}{l}1459 \\
416 \\
50\end{array}$ & $\begin{array}{l}75,80 \\
22,60 \\
2,30\end{array}$ \\
\hline
\end{tabular}

Dari hasil distribusi diatas, usia responden adalah masa reproduksi (2030) tahun. Median umur 29 tahun dan variasi umur 15-49 tahun. Hampir 2/3 akseptor punya anak lebih 2 orang, atau rata-rata 3 orang. Lebih separoh responden punya anak terkecil umur $>2$ tahun. Lebih separoh responden berpendidikan tidak tamat SD dan tamat SD. Sebagian besar pendidikan suami akseptor adalah tamat SD. Pekerjaan terbanyak dari suami akseptor bukan petani.

Tabel.1.2: Analisis Regresi Logistik

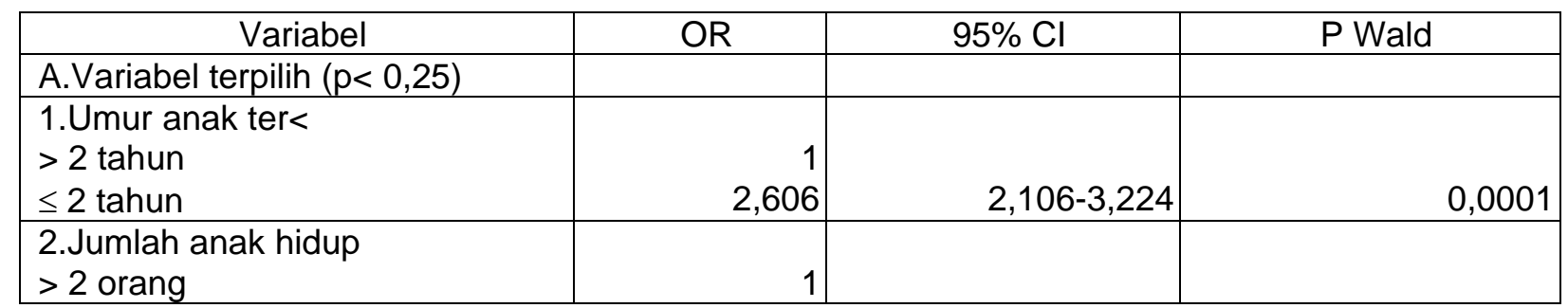

412 |Khazanah Intelektual Volume 3 Nomor 1 Tahun 2019 


\begin{tabular}{|c|c|c|c|}
\hline$\leq 2$ orang & 0,853 & $0,684-1,065$ & 0,1597 \\
\hline $\begin{array}{l}\text { 3.Pendidikan Resp } \\
\text { Pendidikan Rendah } \\
\text { Pendidikan tinggi }\end{array}$ & $\begin{array}{r}1 \\
2,898 \\
\end{array}$ & $2,323-3,620$ & 0,0001 \\
\hline $\begin{array}{l}\text { 4.Pendidikan sumi } \\
\text { Pendidikan rendah } \\
\text { Pendidikan tinggi }\end{array}$ & $\begin{array}{r}1 \\
3,117\end{array}$ & $2,439-3,984$ & 0,0001 \\
\hline $\begin{array}{l}\text { 5.Status Kerja ibu } \\
\text { Tidak } \\
\text { Ya }\end{array}$ & $\begin{array}{r}1 \\
1,220\end{array}$ & $0,978-1,520$ & 0,0776 \\
\hline $\begin{array}{l}\text { 6.Jenis kerja smi } \\
\text { Petani } \\
\text { Bukan tani }\end{array}$ & $\begin{array}{r}1 \\
4,609\end{array}$ & $3,460-6,141$ & 0,0001 \\
\hline $\begin{array}{l}\text { 7.Pengetahuan JI SWT } \\
\text { Tidak tahu } \\
\text { Tahu }\end{array}$ & $\begin{array}{r}1 \\
3,642 \\
\end{array}$ & $2,725-4,869$ & 0,0001 \\
\hline $\begin{array}{l}\text { 8.Petugas KB } \\
\text { Tidak ada } \\
\text { Ada }\end{array}$ & $\begin{array}{r}1 \\
0,771\end{array}$ & $0,77-0,956$ & 0,0176 \\
\hline $\begin{array}{l}\text { 9.Pemilikan } \\
\text { Tidak punya } \\
1 \text { barang } \\
>2 \text { barang } \\
\text { Semua Jns diatas }\end{array}$ & $\begin{array}{r}1 \\
1,636 \\
6,392 \\
7,740 \\
\end{array}$ & $\begin{array}{l}1,165-2,297 \\
4,633-8,819 \\
5,217-11,48\end{array}$ & $\begin{array}{l}0,0045 \\
0,0001 \\
0,0001\end{array}$ \\
\hline $\begin{array}{l}\text { 10.Biaya } \\
\text { Rendah } \\
\text { Sedang } \\
\text { Tinggi }\end{array}$ & $\begin{array}{r}1 \\
12,743 \\
65,759\end{array}$ & $\begin{array}{l}9,560-16,980 \\
40,22-107,60\end{array}$ & $\begin{array}{l}0,0001 \\
0,0001\end{array}$ \\
\hline $\begin{array}{l}\text { 11.Tempat tinggal } \\
\text { Desa } \\
\text { Kota }\end{array}$ & $\begin{array}{r}1 \\
4,508 \\
\end{array}$ & $3,626-5,604$ & 0,0001 \\
\hline $\begin{array}{l}\text { 12. Waktu } \\
\text { Lama } \\
\text { Singkat } \\
\text { Sedang }\end{array}$ & $\begin{array}{r}1 \\
0,87 \\
1,307\end{array}$ & $\begin{array}{l}0,450-1,219 \\
1,513-2,582 \\
\end{array}$ & $\begin{array}{r}0,6814 \\
0,051 \\
\end{array}$ \\
\hline
\end{tabular}

Hasil analisis yang dapat dilihat pada tabel 1.2, Ternyata ada hubungan antara umur anak terkecil dengan penggunaan pelayanan KB jalur swasta. Akseptor yang umur anak terkecilnya $\leq 2$ tahun hampir 3 kali menggunakan pelayanan KB jalur swasta dibandingkan dengan akseptor yang umur anak terkecilnya $>2$ tahun, dengan nilai odds ratio 2 , 606 (95\% Cl: 2,106-3,224, $\mathrm{p}=$ 0,0001).
Responden yang pendidikan tinggi hampir tiga kali kemungkinan menggunakan pelayanan KB jalur swasta dibandingkan dengan akseptor yang pendidikan rendah, dengan nilai odds ratio 2,898 (95\% Cl : 2,323-3,620, $p=0,0001)$.

Suami yang pendidikan tinggi tiga kali kemungkinan lebih besar menggunakan pelayanan KB jalur swasta dibandingkan dengan suami yang pendidikannya rendah dengan 
nilai odds ratio $3,117(95 \% \mathrm{Cl}: 2$, 439-3, 984, $p=0,0001$ ).

Responden yang bekerja 1,2 kali kemungkinan lebih besar menggunakan pelayanan KB jalur swasta dibandingkan yang tidak bekerja dengan nilai odds ratio 1,220 (95\% Cl : 0,978-1,520).

Suami yang bekerja bukan sebagai petani hampir 5 kali kemungkinan lebih besar menggunakan pelayanan KB jalur swasta dibandingkan yang bekerja sebagai petani dengan nilai odds ratio 4,609 (95\% Cl :3,460-6, 141, p $=0,0001)$.

Responden yang mempunyai pengetahuan tentang KB jalur swasta hampir 4 kali kemungkinan lebih besar menggunakan pelayanan KB jalur swasta dibanding yang tidak mengetahui tentang KB jalur swasta, dengan nilai odds ratio 3,642 (95\% $\mathrm{Cl}: 2,725-4,869, \mathrm{p}=0,0001)$.

Akseptor yang memiliki semua jenis barang rumah tangga (televise, radio/kaset, sepeda motor, sampan) hampir delapan kali kemungkinan lebih besar menggunakan pelayanan KB jalur swasta dibandingkan yang tidak punya satupun jenis barang, nilai odds ratio $7,740(95 \% \quad \mathrm{Cl}$ :
5,217-11,48, $p=0,0001)$, Akseptor yang memiliki lebih 2 jenis barang rumah tangga enam kali kemungkinan lebih besar menggunakan pelayanan KB jalur swasta dibandingkan yang tidak memiliki satupun jenis barang, dengan nilai odds ratio 6,392 (95\% Cl : 4,633-8,819, $\quad \mathrm{p}=$ 0,0001). Akseptor yang memiliki satu jenis barang rumah tangga hampir dua kali kemungkinan lebih besar menggunakan pelayanan KB jalur swasta dibandingkan dengan yang tidak memiliki satupun jenis barang, dengan nilai odds ratio 1, 636 (95\% $\mathrm{Cl}: 1,165-2,297, \mathrm{p}=0$, 0045).

Akseptor yang memiliki anak $\leq$ 2 orang ternyata lebih rendah tingkat kemandiriannya, hal ini dapat dilihat dari nilai odds rationya dimana akseptor yang jumlah anak $\leq 2$ orang nilai odds ratio 0, $853(95 \% \mathrm{Cl}$ : 0,684-1, 065, $p=0,1597)$ dan dalam hasil analisis tidak ada perbedaan yang bermakna dalam penggunaan pelayanan KB jalur swasta antara akseptor yang memiliki anak $\leq 2$ orang dengan akseptor yang memiliki anak $>2$ orang.

Biaya pelayanan juga mempengaruhi penggunaan 
pelayanan KB jalur swasta, yaitu akseptor yang mengeluarkan biaya tinggi untuk mendapatkan pelayanan $\mathrm{KB}$, memperoleh pelayanan pada jalur swasta, akseptor yang mengeluarkan biaya >Rp5000 66 kali kemungkinannya mendapatkan pelayanan pada jalur swasta dibandingkan yang mengeluarkan biaya rendah $(<1000)$.

Akseptor yang mengeluarkan biaya antara 1000-5000 hampir 13 kali kemungkinannya mendapatkan pelayanan pada jalur swasta dibandingkan yang mengeluarkan biaya $<1000$.

Akseptor yang mendapat penjelasan tentang keluarga berencana dari petugas $\mathrm{KB}$, ternyata lebih rendah menggunakan pelayanan KB jalur swasta dibandingkan yang tidak mendapatkan penjelasan dari petugas KB.

Akseptor yang bertempat tinggal di kota hampir 5 kali kemungkinannya menggunakan pelayanan KB jalur swasta dibandingkan yang bertempat tinggal di desa.

Akseptor yang membutuhkan waktu sedang (16-30 menit) untuk mencapai lokasi pelayanan KB sekitar 1,3 kali kemungkinanya menggunakan pelayanan $\mathrm{KB}$ jalur swasta dibandingkan yang membutuhkan waktu > 30 menit.

\section{Penilaian " confounding"}

Langkah analisa berikutnya adalah melihat adanya faktor "confounding" (kovariat) terhadap model fit tersebut. Analisis ini melihat apakah variabel umur anak terkecil, jumlah anak, petugas KB, pendidikan responden, pendidikan suami, biaya, pemilikan dan tempat tinggal dapat diikutkan dalam persamaan model hubunggan karakteristik akseptor dengan penggunaan pelayanan $\mathrm{KB}$ jalur swasta, yaitu dengan melihat hasil uji likelihood ratio test, hasilnya dibandingkan dengan nilai kai kuadrat, pada alpha 0,05. 
Tabel.1.3 Hasil analisis regresi logistik multivariabel penilaian variabel kovariat dengan pengetahuan akseptor (variabel utama) terhadap penggunaan pelayanan KB jalur swasta

\begin{tabular}{|l|r|r|r|r|}
\hline Model & -2 log likelihood & Df & G & P \\
\hline 1.Penget KB Jl Swta & 2142,348 & 2127 & & 0,0001 \\
\hline 2.Penget+anak ter< & 2058,728 & 1 & 83,62 & 0,0001 \\
\hline 3.Penget+Pendd resp & 2078,814 & 1 & 63,53 & 0,0001 \\
\hline 4.Penget+Pend suami & 2071,512 & 1 & 70,84 & 0,0001 \\
\hline 5.Penget+St. Krj Res & 2137,170 & 1 & 5,180 & 0,0219 \\
\hline 6.Penget+Jns Kj smi & 2027,610 & 1 & 114,74 & 0,0001 \\
\hline 7.Penget+Pemilikan & 1964,000 & 3 & 179,20 & 0,0001 \\
\hline 8.Penget+Biaya & 1491,100 & 2 & 651,25 & 0,0001 \\
\hline 9.Penget+Jml anak & 2140,790 & 1 & 1,560 & 0,2103 \\
\hline 10.Penget+Pet KB & 2135,500 & 1 & 6,85 & 0,0095 \\
\hline 11.Penget+Temp Tggl & 1984,540 & 1 & 157,81 & 0,0001 \\
\hline 12.Penget+waktu & 2016,750 & 2 & 125,60 & 0,0032 \\
\hline
\end{tabular}

Pada tabel 1.3 terlihat bahwa umur anak terkecil, pendidikan responden, pendidikan suami, status kerja responden jenis pekerjaan suami, pemilikan, biaya, petugas KB, tempat tinggal dan waktu merupakan kovariat, maka keseluruhan variabel tersebut di ikutkan dalam analisis selanjutnya.

Tabel 1.4 Hasil penilaian variabel kovariat terhadap hubungan antara pengetahuan akseptor dengan penggunaan pelayanan KB Jalur Swasta

\begin{tabular}{|l|l|l|}
\hline Variabel & Odds ratio & Beda OR \% \\
\hline 1.Pengetahuan KB jalur swasta & 3,643 & \\
\hline 2.Penget KB + Umur anak ter $<$ & 3,898 & 6,590 \\
\hline 3.Penget KB + Stat kerja resp & 3,732 & 2,390 \\
\hline 4.Penget KB + Jns kerja suami & 2,870 & $26,901\left(^{*}\right)$ \\
\hline 5.Penget KB + Penddk responden & 2,664 & $35,226\left(^{*}\right)$ \\
\hline 6.Penget KB + Penddk suami & 2,939 & $23,954\left({ }^{*}\right)$ \\
\hline 7.Penget KB + Pemilikan & 2,133 & $70,808\left(\left(^{*}\right)\right.$ \\
\hline 8.Penget KB + biaya & 3,022 & $20,537\left(\left(^{*}\right)\right.$ \\
\hline 9.Penget KB + tempat tinggal & 2,687 & $35,553\left(^{*}\right)$ \\
\hline 10.Penget KB + petugas KB & 3,697 & 1,460 \\
\hline 11.Penget KB + Waktu & 3,676 & 0,901 \\
\hline
\end{tabular}


Pada tabel 1.4 ditampilkan nilai perbedaan odds ratio dari variabel umur anak terkecil, status kerja responden, jenis pekerjaan suami, pendidikan responden, pendidikan suami, pemilikan, biaya, petugas $\mathrm{KB}$, waktu dan tempat tinggal

Tabel 1.5 Harga odds ratio variabel utama (pengetahuan KB jalur swasta) dan konvariat terhadap penggunaan pelayanan $\mathrm{KB}$ jalur swasta

\begin{tabular}{|c|c|c|c|c|c|c|}
\hline Variabel & Beta & SE & OR & Wald & $95 \% \mathrm{Cl}$ & $P$ \\
\hline .Pengetahuan KB & 0,716 & 0,203 & 2,054 & 3,527 & $\begin{array}{r}1,374- \\
3,046\end{array}$ & 0,0004 \\
\hline $\begin{array}{l}\text { 9.Pendidikan Responden SD } \\
\text { kebawah }\end{array}$ & 0,064 & 0,166 & 0,938 & 0,388 & $\begin{array}{r}0,677- \\
1,299 \\
\end{array}$ & 0,6979 \\
\hline 3.Pend suami SD kebawah & 0,279 & 0,177 & 1,323 & 1,579 & $\begin{array}{r}0,935- \\
1,871\end{array}$ & 0,114 \\
\hline 1.Jns Kj smi & 0,461 & 0,189 & 1,586 & 2,433 & $\begin{array}{r}1,093- \\
2,299\end{array}$ & 0,0151 \\
\hline $\begin{array}{l}\text { Biaya }(\mathrm{Sdg}) \\
\text { tinggi }\end{array}$ & $\begin{array}{l}3,565 \\
2,431\end{array}$ & $\begin{array}{l}0,270 \\
0,155\end{array}$ & $\begin{array}{l}35,34 \\
15,68\end{array}$ & $\begin{array}{l}13,204 \\
11,370\end{array}$ & $\begin{array}{r}20,82- \\
60,03 \\
8,393- \\
15,41\end{array}$ & $\begin{array}{l}0,0001 \\
0,0001\end{array}$ \\
\hline $\begin{array}{l}\text { Pemilikan } \\
\text { semua } \\
>2 \text { barang } \\
1 \text { barang }\end{array}$ & $\begin{array}{l}0,652 \\
0,986 \\
0,419\end{array}$ & $\begin{array}{l}0,257 \\
0,204 \\
0,199\end{array}$ & $\begin{array}{l}1,919 \\
2,682 \\
1,520\end{array}$ & $\begin{array}{l}2,537 \\
4,833 \\
2,106\end{array}$ & $\begin{array}{r}1,159- \\
3,175 \\
1,798- \\
4,033 \\
1,029- \\
2,245\end{array}$ & $\begin{array}{l}0,0111 \\
0,0001 \\
0,0353\end{array}$ \\
\hline .Tempat tinggal & 0,794 & 0,148 & 2,211 & 5,365 & $\begin{array}{r}1,653- \\
2,598\end{array}$ & 0,0001 \\
\hline
\end{tabular}

\section{PENUTUP}

\section{Kesimpulan}

Berdasarkan hasil penelitian dan pembahasan dapat diambil kesimpulan sebagai berikut:

1. Tidak terdapat hubungan antara umur responden, jumlah anak dan status kerja ibu dengan penggunaan pelayana KB jalur swasta
2. Terdapat hubungan antara karakterstik sosial ekonomi (pendidikan responden, pendidikan suami, jenis pekerjaan suami, pemilikan barang, biaya) dengan penggunaan pelayanan KB jalur swasta.

3. Terjadi hubungan negatif antara kunjungan petugas $\mathrm{KB}$ 
dengan penggunaan pelayanan KB jalur swasta, karena responden yang dikunjungi petugas lebih banyak menggunakan pelayanan $\mathrm{KB}$ jalur pemerintah dibanding jalur swasta.

4. Akseptor yang tinggal di kota hampir 5 kali lebih besar kemungkinan menggunakan pelayanan KB jalur swasta dibandingkan yang tinggal di desa "OR" 4,508 (95\% Cl: 3,626-5,604, $p=0,0001$

5. Terdapat 6 variabel independen yang merupakan kovariat terhadap pengetahuan KB jalur swasta (pendidikan responden, pendidikan suami, jenis pekerjaan suami, biaya, pemilikan dan tempat tinggal)

6. Terjadi interaksi antara pengetahuan tentang KB jalur swasta dengan pendidikan responden, yaitu responden yang pendidikan lebih tinggi (tamat SD keatas) dan tahu jalur swasta 2 kali lebih besar kemungkinan menggunakan pelayanan KB jalur swasta dengan presisi yang baik.

\section{DAFTAR PUSTAKA}

Audet MC. et al. Evaluation of contraceptive efficacy and cycle control of a transdermal contraceptive Patch vs an oral contraceptive:A Randomized Controlled Trial. Jama: 2001;285:2347-54.

Aryekti Kanthi, Kualitas pelayanan keluarga berencana jalur swasta dan pemerintah di Kabupaten Purworejo. [Yogyakarta] : Universitas Gadjah Mada, 2000

BPS Statistik Indonesia 2017 (Statistical Yearbook of Indonesia 2017).

BKKBN. Pedoman Kebijakan Tehnis Keluarga Berencana dan Kesehatan Reproduksi, Jakarta.2001.

BKKBN. Keluarga Berencana dan Kesehatan

Reproduksi: Kebijakan, Program dan Kegiatan Tahun 2005-2009. Jakarta.2005.

Bertrand JT.New Attentionto the IUD. Population Report,2006; 6(7):111.

Barrett J, Buckley,C. Constrained contraceptive choice: IUD prevalence in Uzbekistan. International Family Planning Perspectives, 2007;33 (2): 50-57.

Bruce,Yudith. Enam unsur kualitas pelayanan, suatu kerangka pikir sederhana. Diterjemahkan oleh Peter Haguel. 1992

David Osears, et.all. Psikologi sosial. Edisi ke $\mathrm{V}$ jilid 1, Penerbit 
Erlangga (alih bahasa Michael Adryanto \& Savitri Soekarno. 1988

Debpuur C. et al. The impact of the Navrongo Project on contraceptive knowledge and use, reproductive preferences, and fertility, Studies in Family Planning, 2002;33 (2):141-64.

Eckhom, Erik \& Newland Kathleen. Wanita, kesehatan dan keluarga berencana. Diterjemahkan oleh Maris Masri dan Ny. Sukarto.1977

Finkle L, Jason dan Michitos, C Alison. The New Polities of Population and Development Review. Assuplement to vol.20. Diterjemahkan oleh Sudarmanto, Editor Bambang Purmantoro.1994

Hakim Rozana. Ciri-ciri peserta KB Mandiri dalam pengembangan KB swasta di DKI Jakarta. Tesis bidang Kesehatan Masyarakat Program Pascasarjana UI-Jakarta. 1988

Harjono, Dasuki D, Sudargo T. Determinan kemandirian peserta KB di Kabupaten Purworejo. Berita Kedokteran Masyarakat, 2001;XVII(4):209-17

Hatcher RA, Rinehart W, Blackhura R, Geler GS, and Shelton JD. The essentials of contraceptive technology. Baltimore Johns Hopkins Bloomberg School of Public Health. Population Information rogram.2003.
Katz KR. et al. Increasing access to Family Planning Services in rural Mali Through Community baseddistribution. International Family PlanningPerspectives, 1998;24(3): 104-110.

Sri Panuntun, dkk. Berita Kedokteran Masyarakat, Hubungan Antara Akses KB Vol. 25, No. 2, Juni 2009

Sigit K, Pengaruh jumlah anak dan keinginan punya anak terhadap penggunaan kontrasepsi di Propinsi Jawa Tengah. Berita Kedokteran Masyarakat, 2000; XVI (2):8395.

Verma RK, Baburajan PK. Determinant of contraceptive choice in India. Journal of family welfare,1994; 40(3):1-8.

http://www.lusa.web.id/program-kbdi-indonesia/

http://dwiyulianiadnan27.blogspot.co $\mathrm{m} / 2013 / 11$ program-kb-diindonesia.html

http://minirukmini.blogspot.com/2013 /05/persepsi-dan-partisipasimasyarakat.html 